\title{
LITERASI TEKNOLOGI DALAM PERSPEKTIF CALON PENDIDIK SEKOLAH DASAR: SEBUAH ANALISIS KEBUTUHAN
}

\section{Nina Suzanne}

Institut Agama Islam Negeri Batusangkar

Email: ninasuzanne@iainbatusangkar.ac.id

Naskah diterima : 10 Agustus 2019, direvisi : 5 September 2019, disetujui : 18 September 2019

\begin{abstract}
The era of the industrial revolution 4.0 was marked by the use of massive and critical technology. Almost everyone has a smartphone with $4 \mathrm{G}$ internet connection for communication and having information around the world rapidly. Students also get the advantage to do their assignment, get more interactive media for learning, or just for fun in social media. However, a negative impact cannot be avoided if the students do not understand how to use technology wisely. Therefore, technology literacy is needed to give the students a strong basis in using technology to support their activities. This research aims to describe students' perceptions of the importance of technology literacy for students and candidate teachers. The informants were 23 PGMI students of IAIN Batusangkar who were given openended questionnaires about their perspective on the use of technology in the teaching and learning process. The results describe that the use of technology such as smartphones wisely with good knowledge on it is a must. Being innovative, creative, and dynamic are expected from students and candidate teachers as well
\end{abstract}

Keywords: Skills, Thinking, High, Books, Thematic, Low.

Pengutipan: Nina Suzanne. (2019). Literasi Teknologi dalam Perspektif Calon Pendidik Sekolah Dasar: Sebuah Analisis Kebutuhan. JMIE: Journal of Madrasah Ibtidaiyah Education,3(2), 2019, 118-129. jmie.v3i2.127.

Permalink/DOI: http://dx.doi.org/ 10.32934/jmie.v3i2.127 


\section{PENDAHULUAN}

Era millenium atau yang disebut juga dengan era digital ditandai dengan perkembangan teknologi yang sangat pesat. Alat-alat canggih seperti smartphone, notebook layar sentuh serta jaringan internet yang luas dan cepat merupakan bahagian dari kecanggihan teknologi. Teknologi yang serba canggih ini juga masuk ke dalam dunia pendidikan. Zaman sekarang, proses pembelajaran di dalam kelas sudah didukung oleh media pembelajaran yang berbasis digital. Tidak hanya di sekolah tinggi namun juga sekolah menengah bahkan sekolah dasar dan paud. Media pembelajaran ini seperti video, audio, gambar, objek nyata, dan lain sebagainya merupakan sebuah perantara atau pengantar pesan dari si pengirim (guru) ke penerima pesan (anak didik). Sadiman, dkk (2011). Senada dengan pendapat tersebut, Briggs dalam Sadiman, dkk (2011) juga menjelaskan bahwa media adalah segala alat fisik yang dapat menyajikan pesan dan merangsang siswa untuk belajar. Media tersebut bisa berupa buku, film, kaset, objek, dan lain-lain.

Sebelum era digital ini, media sesungguhnya sudah menjadi bahagian dari proses pendidikan. Media pembelajaran dipergunakan untuk menyampaikan pesan pembelajaran untuk mempermudah proses pembelajaran dan menimbulkan suasana yang lebih menarik dan menyenangkan (Sanaky, 2009). Namun perkembangan teknologi memberikan perhatian khusus akan aspek desain atau tampilannya, pengembangan pembelajaran dan juga evaluasi yang dipergunakan. Seorang guru ataupun calon guru sudah sepatutnya memahami dan mengaplikasikan segala hal yang dapat mendukung terjadinya suatu proses pembelajaran yang lebih komunikatif, menarik, efektif, dan bermakna.

Media yang digunakan dalam pendidikan banyak sekali macamnya. Ditinjau dari aspek pengadaannya, media dibagi atas dua, yaitu media jadi atau media siap pakai (media by utilization), dan media rancangan yang dipersiapkan secara khusus (media by design). Sadiman, dkk (2011). Media yang sudah jadi dapat dipergunakan langsung oleh guru dan anak didik dalam proses pembelajaran. Namun sebaliknya, media rancangan dipersiapkan oleh guru secara khusus sesuai dengan kebutuhan pembelajaran dengan mempertimbangkan berbagai aspek seperti kemudahan penggunaannya, sesuai kebutuhan siswa atau tidak, sesuai dengan tujuan pembelajaran atau tidak, dan aspek-aspek lainnya.

Kedua jenis media tersebut memiliki kelebihan dan kelemahan masing-masing. Sesungguhnya, guru atau calon guru dapat menggunakan kedua media tersebut. Namun dengan perkembangan teknologi yang semakin canggih dari waktu ke waktu, guru atau calon guru tidak diharapkan untuk hanya menggunakan media yang sudah jadi, namun juga mampu untuk mengembangkan media yang lebih sesuai dan tepat untuk dipergunakan sesuai dengan karaktersitik anak didiknya. Hal ini untuk meminimalisir kurang validnya media yang dipergunakan sekaligus memenuhi ketersediaan media yang sesuai untuk anak didik. (Sumantri, 2016; Susanto, 2013). 
Pemanfaatan teknologi nyatanya tidak hanya memberikan dampak positif namun juga banyak sisi negatifnya. Kemudahan akses membuat guru ataupun calon guru memperoleh banyak sekali sumber yang dapat dipergunakan dalam pembelajaran. Namun jika tidak disaring dengan baik, guru dapat saja memberikan informasi-informasi yang keliru kepada anak didiknya, gaya bahasa yang kurang sesuai, dan juga konteks yang jauh dari yang bisa dibayangkan anak didik, atau alat-alat yang tidak praktis untuk diterapkan karena keterbatasan sarana pendukungnya. Dengan demikian, penggunaan teknologi tidak boleh melebihi kapasitas. Ada batas-batas yang harus dipenuhi karena tidak selamanya proses pembelajaran harus dilakukan dengan teknologi yang canggih. Mengenai hal ini, Shyamlee dan Phil (2012) dalam penelitian mereka tentang pemanfaatan teknologi dalam pembelajaran mengemukakan bahwa teknologi sebagaimana halnya multimedia tidak boleh dipergunakan secara berlebihan. Karena ternyata tampilan teknologi dapat mengurangi perhatian siswa terhadap materi yang sedang dipelajari.

Literasi sebagai suatu gerakan yang sangat keras gaungnya dalam dunia pendidikan juga memberikan perhatian khusus terhadap kemajuan tekonologi. Literasi yang tidak hanya terbatas pada melek baca dan tulis juga berkembang menjadi multi-literacy yang salah satunya adalah literasi teknologi. Pengembangan media pembelajaran merupakan bahagian dari literasi teknologi. Seseorang dikatakan literat jika ia mampu memahami sesuatu dari informasi yang tepat dan melakukan sesuatu berdasarkan pemahamnnya tersebut. (Permatasari, 2015). Literasi teknologi menjadi sangat krusial bagi guru dan calon guru era digital. Tidak terkecuali bagi mahasiswa Pendidikan Guru Madrasah Ibtidaiyah yang merupakan calon pendidik di sekolah dasar. Perlu dipahami dengan jelas bahwa siswa sekolah dasar memiliki karakteristik yang unik dimana mereka mengalami pertumbuhan dan perkembangan yang sangat signifikan. Anak usia sekolah dasar memiliki kecendrungan belajar dengan ciri-ciri konkret, integratif, dan hierarkis. Konkret maksudnya adalah anak belajar beranjak dari hal-hal yang dapat dilihat, didengar, dibaui, diraba, dan diotak-atik. Integratif maksudnya anak usia sekolah dasar memandang sesuatu yang dipelajari sebagai suatu keutuhan dengan cara berfikir deduktif. Sementara hierarkis maksudnya adalah siswa belajar secara bertahap dari hal-hal sederhana ke hal-hal yang lebih kompleks. (Sumantri, 2015). Karena itulah, pemanfaatan teknologi dalam pendidikan tidak boleh dilepaskan dari karakteristik siswa yang akan mendapatkan dampak pemanfaatannya secara optimal.

Guru sangat berperan dalam merangsang siswa untuk belajar dan memiliki motivasi yang tinggi untuk menjadi siswa yang aktif dan kreatif. Karena itulah guru harus mampu mengembangkan pembelajaran yang tepat agar potensi siswa dapat berkembang sepantasnya. Guru harus mampu memilih bahan ajar, media pembelajaran yang berkualitas dan mendorong siswa untuk memanfaatkan teknologi secara positif. (Teguh, 2017). 
Dengan demikian, gerakan literasi teknologi sangat penting untuk menumbuhkembangakan kreatifitas dan daya cipta seorang guru, calon pendidik, dan anak didik itu sendiri. Secara sederhana, literasi teknologi bermakna melek teknologi. Beberapa teori mengemukakan definisi dari literasi teknologi yang hampir sama. Literasi teknologi merupakan pemahaman, pemanfaatan, penghargaan, dan pengembangan dari teknologi yang dapat dipergunakan dalam dunia pendidikan. (Maryland technology Education State Curriculum, 2005; National Academy of Engineering and National Research Council of the National Academis, 2006; Rose, 2007). Pengertian tersebut mengindikasikan bahwa dalam literasi teknologi, guru maupun anak didik diharapkan menjadi pengguna teknologi yang aktif bukan pasif. Maksudnya tidak serta merta teknologi yang ada dapat dimanfaatkan dalam pembelajaran. Ada kalanya teknologi yang ada harus dikembangkan agar sesuai dan lebih bermanfaat bagi anak didik.

Tulisan ini bertujuan untuk mengkaji secara mendalam bagaimana perspektif calon pendidik sekolah dasar terhadap literasi teknologi yang merupakan suatu analisis kebutuhan terhadap pengembangan media pembelajaran yang dapat dipergunakan di dunia pendidikan.

\section{METODE PENELITIAN}

Jenis penelitian ini adalah penelitian kualitatif dengan desain deskriptif kualitatif yang menjaring perspektif calon pendidik terhadap pentingnya literasi teknologi dalam pembelajaran. Peneliti melibatkan 23 orang mahasiswa PGMI IAIN Batusangkar sebagai responden penelitian yang dipilih secara random. Adapun instrumen yang digunakan adalah angket terbuka yang dibuat berdasarkan aspek-aspek analisis kebutuhan yang terdiri dari necessities, lack dan want. (Huchinson and Waters, 1987). Angket tersebut terdiri dari 11 pertanyaan yang masing-masingnya diberi alternatif jawaban dan juga kolom untuk diisi oleh responden. Teknik analisis data yang digunakan mengikuti langkah-langkah analisis data penelitian kualitatif dengan melakukan reduksi data, penyajian data, interpretasi data, dan penarikan kesimpulan. (Miles and Huberman, 1994).

\section{TEMUAN DAN PEMBAHASAN}

Hasil analisis terhadap data yang dikumpulkan melalui angket terbuka memberikan gambaran yang jelas terhadap sudut pandang partisipan terhadap literasi teknologi yang perlu digiatkan untuk mendukung pembelajaran khususnya bagi calon pendidik sekolah dasar yang harus senantiasa siap sedia membekali dirinya dengan berbagai pengetahuan dan keterampilan salah satunya dalam memanfaatkan teknologi dalam pembelajaran. Pertanyaan-pertanyaan yang diberikan kepada partisipan dibagi ke dalam tiga aspek yaitu necessities, lack dan wants yang merupakan indikator yang diperlukan dalam melakukan analisis kebutuhan. Data yang 
diperoleh memberikan gambaran bagaimana sesungguhnya kebutuhan partisipan dalam memanfaatkan teknologi, tidak hanya menggunakan yang sudah ada namun mampu mengembangkannya untuk mendukung pembelajaran.

Aspek necessities terdiri dari 4 pertanyaan yang bertujuan untuk mengetahui apa sebenarnya kebutuhan dan tujuan partisipan dalam memanfaatkan teknologi dalam pembelajaran. Data yang diperoleh dapat dilihat pada tabel 1.

Tabel di atas menginformasikan bahwa partisipan memanfaatkan teknologi agar menjadi calon pendidik yang lebih kreatif, inovatif dan inisiatif. Lebih dari separo partisipan mengungkapkan hal ini berarti mereka berpandangan bahwa penting untuk lebih canggih dan melek teknologi dalam pendidikan. Lowther et al dalam Fu (2013) mengungkapkan bahwa ada tiga karakteristik yang harus dimiliki untuk mengembangkan kualitas pembelajaran dengan memanfaatkan teknologi, yaitu otonomi, kapabilitas, dan kreatifitas. Otonomi memberikan kebebasan pada siswa untuk mengontrol pembelajarannya. Mereka juga memiliki kemampuan untuk bekerja sendiri ataupun bersama-sama dan memiliki kesempatan yang seluas-luasnya untuk mengembangkan pengetahuan dengan lebih percaya diri.

Hal ini didukung oleh pernyataan ke-dua bahwa teknologi apa saya yang dibutuhkan dan sebahagian besar mereka menjawab smartphone dan jaringan internet. Tidak dapat dipungkiri bahwa smartphone merupakan kebutuhan wajib bagi millenial. Dapat dikatakan hampir setiap orang memiliki smartphone dengan fitur-fitur yang canggih. Namun, samrtphone tanpa jaringan internet juga akan percuma sehingga dari jawaban partisipan terlihat bahwa kedua aspek kemajuan teknologi ini sangat mereka butuhkan untuk mendukung keberhasilan proses pembelajaran. Sudjana dan Rivai (2011) mengemukakan bahwa kecanggihan media tidak meninggikan nilai sebuah media dalam pembelajaran, yang penting adalah bagaimana fungsi dan peranannya dalam membantu proses pengajaran.

Tabel 1. Kebutuhan dan Tujuan Memanfaatkan Teknologi

\begin{tabular}{|c|c|c|}
\hline Pernyataan & Respon & Persentase \\
\hline \multirow[t]{3}{*}{$\begin{array}{l}\text { Alasan menggunakan teknologi } \\
\text { dalam pembelajaran }\end{array}$} & $\begin{array}{l}\text { 1. Untuk lebih inisiatif, inovatif, dan } \\
\text { kreatif }\end{array}$ & $60.9 \%$ \\
\hline & 2. Saling berbagi informasi & $56.5 \%$ \\
\hline & $\begin{array}{l}\text { 3. Agar dapat mengembangkan } \\
\text { pengetahuan }\end{array}$ & $43.5 \%$ \\
\hline \multirow[t]{2}{*}{ Teknologi yang dibutuhkan } & 1. Jaringan internet & $82.6 \%$ \\
\hline & 2. Smartphone & $60.9 \%$ \\
\hline \multirow[t]{2}{*}{$\begin{array}{l}\text { Keterampilan yang dibutuhkan } \\
\text { dalam memanfaatkan teknologi }\end{array}$} & $\begin{array}{l}\text { 1. keterampilan } \\
\text { dokumen }\end{array}$ & $56.5 \%$ \\
\hline & 2. keterampilan berkomunikasi dan & $47.8 \%$ \\
\hline
\end{tabular}




\begin{tabular}{llc}
\hline \multicolumn{1}{c}{ Pernyataan } & \multicolumn{1}{c}{ Respon } & Persentase \\
\hline $\begin{array}{l}\text { Target yang ingin dicapai dengan } \\
\text { teknologi }\end{array}$ & $\begin{array}{l}\text { 1. } \begin{array}{l}\text { menganalisis informasi } \\
\text { dan benar }\end{array} \\
\text { 2. menyelesaikan tugas dan yang } \\
\text { lainnya }\end{array}$ & $65.2 \%$ \\
\hline
\end{tabular}

Selanjutnya, teknologi setinggi apapun tanpa pengetahuan dan keterampilan yang memadai untuk memanfaatkannya juga akan percuma. Sehingga ada beberapa keterampilan yang mesti dimiliki dan partisipan berpandangan bahwa terampil dalam mengelola dokumen dan juga terampil dalam berkomunikasi dan menganalisis informasi menjadi keterampilan yang mesti mereka miliki. Ini mengindikasikan bahwa partisipan juga berkeinginan untuk memiliki keteraturan dalam berteknologi dan mendapatkan kemudahan dalam akses. Dengan memiliki keterampilan berteknologi tentunya target yang diinginkan bisa dicapai. Sebagaimana yang digambarkan oleh penyataan ke-4 bahwa sebagai calon pendidik yang inovatif dan kreatif tentunya memiliki target yang ingin dicapai dengan memanfaatkan teknologi. Sebanyak $65.2 \%$ partisipan menjawab ingin mengoperasikan peralatan dengan tepat dan benar, dan $60.9 \%$ menyatakan untuk menyelesaikan berbagai tugas. Informasi yang diberikan dari pernyataan ini bahwa teknologi menghendaki penggunanya untuk dapat mengoperasikannya dengan tepat dan benar sehingga dapat membantu pengguna dalam menyelesaikan tugas-tugasnya dengan baik dan tepat waktu.

Tujuan dalam penggunaan teknologi sebagai media pembelajaran tidak akan dapat tercapai sesuai harapan karena adanya beberapa penghalang. Berikut adalah aspek lacks yang memberikan gambaran adanya gap antara kondisi partisipan saat ini dan kondisi ideal yang diharapkan terkait pemanfaatan teknologi. Ada 3 pertanyaan yang diajukan terkait aspek ini. Data yang diperoleh tergambar dalam tabel 2 berikut.

Tabel 2. Kondisi Sebenarnya dan Kondisi Ideal

\begin{tabular}{llc}
\hline \multicolumn{1}{c}{ Pernyataan } & \multicolumn{1}{c}{ Respon } & Persentase \\
\hline $\begin{array}{l}\text { Hambatan dalam menggunakan } \\
\text { teknologi dalam pembelajaran }\end{array}$ & 1. Keterbatasan dana & $56.5 \%$ \\
& & \\
& 2. Lambannya koneksi internet & $52.2 \%$ \\
& 3. Kurangnya pengetahuan dalam & $52.2 \%$ \\
Untuk apa digunakannya teknologi & pengaplikasian teknologi & \\
& 1. Presentasi perkuliahan & $56.5 \%$ \\
& 2. Proses pembelajaran & $52.2 \%$ \\
& 3. Pengembangan & pembelajaran dan bahan ajar \\
& &
\end{tabular}




\begin{tabular}{cccc}
\hline Pernyataan & \multicolumn{1}{c}{ Respon } & Persentase \\
\hline Manfaat yang dirasakan & $\begin{array}{l}\text { 1. } \\
\text { Memacu kreativitas mahasiswa dan } \\
\text { guru }\end{array}$ & $60.9 \%$ \\
2. $\begin{array}{l}\text { Membantu mahasiswa dalam } \\
\text { belajar }\end{array}$ & $52.2 \%$ \\
\hline
\end{tabular}

Tabel 2 di atas menggambarkan bahwa canggihnya teknologi tidak membuat orang bisa segalanya. Ternyata ada berbagai hambatan yang dihadapai yang menyebabkan pemanfaatan teknologi tidak maksimal. Jawaban partisipan yang paling tinggi persentasenya adalah masalah keterbatasan dana. Sebanyak 56.5\% partisipan mengungkapkan hal tersebut. Hal ini tentunya wajar mengingat mahasiswa pada umumnya belum memiliki kemandirian dalam pendanaan perkuliahan dan masih bergantung pada orang tua.

Hambatan berikutnya yang dihadapi partisipan adan lambannya koneksi internet. Jaringan yang tidak kuat dan maksimal membuat canggihnya teknologi jadi tidak berarti karena tidak mampu mendukung kebutuhan penggunanya. Zaman sekarang mahasiswa tentunya tidak perlu lagi ke warnet karena sudah punya smartphone dengan paket internet tertentu dalam mencari tugas-tugas perkuliahan. Jika jaringan internet tidak bagus tentunya dapat memperlambat mahasiswa dalam menyelesaikan tugas mereka. Demikian juga dengan keterampilan penggunaan teknologi yang tidak mumpuni. Sebanyak 52.2\%, sama dengan keterbatasan jaringan internet, mengemukakan bahwa mereka belum maksimal dalam pemanfaatan teknologi modern karena belum bisa mengoperasikan peralatannya secara maksimal. Sehingga dapat disimpulkan bahwa masalah yang dihadapi mahasiswa dalam pemanfaatan teknologi dalam pembelajaran disebabkan faktor internal (kompetensi/skill) dan eksternal (jaringan internet). Sebagaimana yang dikemukakan oleh Sumantri (2016) bahwa keterbatasan dalam pemahaman dan keterampilan memanfaatkan teknologi dapat menimbulkan penyalahgunaan teknologi dan tidak terpakainya teknologi secara optimal.

Berikutnya, pertanyaan mengarah pada untuk apa saja teknologi dipergunakan. Sebahagian besar partisipan menjawab untuk presentasi perkuliahan dan mendukung proses pembelajaran. Ada juga diantara mereka yang menjawab untuk dapat melakukan pengembangan terhadap media pembelajaran dan materi ajar (43.5\%). Walaupun tidak sampai separo yang mengungkapkan hal tersebut, jawaban partisipan cukup menarik untuk dibahas bahwa ternyata diantara mahasiswa ada yang memandang jauh ke depan bahwa apa yang sudah ada belum tentu dapat dimanfaatkan secara maksimal untuk mendukung pembelajaran sehingga dirasa perlu untuk dikembangkan dan disesuaikan dengan kebutuhan dan karakterisitik subjek yang akan menggunakannya atau mendapatkan manfaat dari penggunaan teknologi. Sebagaimana yang dikemukakan oleh Sadiman, dkk (2011) bahwa pengembangan dalam pembelajaran diperlukan dengan melakukan analisis kebutuhan dan memperhatikan karakteristik siswa. 
Terakhir, manfaat yang dirasakan dengan digunakannya teknologi dalam pembelajaran diantaranya adalah memacu kreativitas guru dan siswa. Jika sebelumnya guru atau dosen banyak menjelaskan dan hanya menggunakan papan tulis secbagai media pendukung, dengan kecanggihan teknologi, mereka dapat menampilkan video-video pembelajaran, menggunakan materi ajar yang berbasis digital, bahkan melakukan e-learning (pembelajaran jarak jauh). Sebanyak 60.9\% partisipan menjawab hal ini. Sementara itu sebanyak 52.2\% partisipan menjawab bahwa teknologi dapat membantu mahasiswa dalam belajar. Berbagai kemudahan dapat diperoleh mahasiswa diantaranya lebih cepat memperoleh informasi dan memperoleh sumber yang lebih banyak dan variatif.

Aspek terakhir yang akan dibahas adalah wants atau bagaimana mahasiswa mencapai tujuannya. Ada 4 pertanyaan yang menjaring sudut pandang mahasiswa terkait caranya memanfaatkan teknologi untuk perkuliahan maupun untuk persiapan mengajar di SD/MI nantinya. Penjelasan masing-masingnya dapat dilihat pada tabel 3 dibawah ini.

\section{Tabel 3. Cara Memanfaatkan Teknologi}

\begin{tabular}{|c|c|c|}
\hline Pernyataan & Respon & Persentase \\
\hline \multirow[t]{2}{*}{$\begin{array}{l}\text { Cara memanfaatkan teknologi } \\
\text { untuk tugas perkuliahan }\end{array}$} & 1. Memiliki tujuan positif & $73.9 \%$ \\
\hline & $\begin{array}{l}\text { 2. Mencari sumber informasi yang } \\
\text { valid dan kredibel }\end{array}$ & $52.2 \%$ \\
\hline \multirow{2}{*}{$\begin{array}{l}\text { Cara memanfaatkan teknologi } \\
\text { untuk persiapan mengajar di } \\
\text { SD/MI }\end{array}$} & $\begin{array}{l}\text { 1. Mencari berbagai media yang fun } \\
\text { dan enjoy }\end{array}$ & $65.2 \%$ \\
\hline & $\begin{array}{l}\text { 2. Membuat video-video yang } \\
\text { menarik }\end{array}$ & $43.5 \%$ \\
\hline \multirow{2}{*}{$\begin{array}{l}\text { Teknologi yang efektif untuk } \\
\text { pembelajaran SD/MI }\end{array}$} & 1. Media yang kreatif dan menarik & $56.5 \%$ \\
\hline & $\begin{array}{l}\text { 2. Media dan materi ajar yang } \\
\text { mudah dipahami dan } \\
\text { meningkatkan semangat siswa } \\
\text { dalam belajar }\end{array}$ & $52.2 \%$ \\
\hline \multirow[t]{2}{*}{$\begin{array}{l}\text { Peran guru dalam pengembangan } \\
\text { teknologi }\end{array}$} & $\begin{array}{l}\text { 1. Pengembang dan perencana } \\
\text { pembelajaran yang menarik }\end{array}$ & $82.6 \%$ \\
\hline & 2. Sebagai fasilitator & $47.8 \%$ \\
\hline
\end{tabular}


Tabel 3 di atas memberikan gambaran bahwa penggunaan teknologi ternyata erat kaitannya dengan tiga aspek yaitu proses pembelajaran, media pembelajaran, dan materi ajar yang menarik, menyenangkan, dan berkualitas. Partisipan meyakini bahwa teknologi patut dipergunakan secara positif dan bijak. Memang tidak semua yang terkait dengan teknologi modern yang bermanfaat dan mendukung pembelajaran. Terlalu banyak main games, terlalu asyik dengan sosial media, tidak kritis dalam memilih materi/informasi justru akan memberi dampak negatif bagi mahasiswa. Ternyata sebanyak $73.9 \%$ partisipan memberikan respon terhadap penggunaan teknologi secara positif. Temuan ini juga didukung oleh hasil penelitian dari Gorra dan Bhati (2016) yang mengemukakan bahwa pada umumnya mahasiswa di perguruan tinggi di Philipina menggunakan teknologi untuk tujuan positif dimana teknologi dianggap dapat membantu dan meningkatkan proses pembelajaran mereka di kelas dengan lebih baik lagi. Ini mengindikasikan bahwa teknologi memang diharapkan dapat memberikan nuansa baru dalam pembelajaran yang lebih efektif dan menarik.

Senada dengan penjelasan di atas, sebagai persiapan mendidik siswa sekolah dasar, sebanyak $65.2 \%$ partisipan beranggapan bahwa mereka menggunakan teknologi sebagai media pembelajaran yang menyenangkan dan menarik bagi siswa. 43.5\% bahkan mengemukakan perlunya kreatifitas untuk membuat konten-konten video yang dapat dipergunakan di dalam kelas agar siswa lebih termotivasi untuk belajar. Pada umumnya, partisipan beranggapan bahwa media yang kreatif, menarik dan tentunya inovatif dapat memicu semangat siswa untuk belajar lebih aktif. Namun, media tersebut harus mudah dan tidak rumit untuk dipergunakan. Anak usia sekolah dasar memang memiliki ciri suka bermain dan mudah dipengaruhi lingkungan. Dengan demikian suasana pembelajaran di sekolah dasar perlu kondusif dan menyenangkan. (Susanto, 2013).

Terakhir, peran guru dalam pengembangan teknologi ternyata cukup krusial. Selain sebagai fasilitator, guru seharusnya tidak hanya bisa memanfaatkan teknologi yang ada, namun harus berinovasi dan mengembangkan media ataupun materi ajar agar lebih sesuai dengan kebutuhan siswanya. Tantangan seorang guru adalah memiliki pengetahuan yang memadai, memiliki keterampilan menggunakan teknologi, dan mengembangkan berbagai media sesuai kebutuhan. (Sanaky, 2009). Hal senada juga diungkapkan oleh Courville (2011) dalam artikelnya yang menjelaskan bahwa dengan adanya teknologi yang didukung oleh jaringan internet yang memadai, guru tidak hanya mengandalkan informasi dan berbagai pelatihan dari pihak-pihak yang berwenang dalam pendidikan, namun mereka juga dapat mengembangkan konten pembelajaran dan berbagi dengan kolega. Guru dapat selangkah lebih maju dan profesional dibidangnya dengan berkecimpung dengan teknologi dan tidak harus menunggu panggilan untuk pelatihan dalam mengembangkan kapasitasnya. 
Teknologi memang tidak akan menggantikan peranan seorang guru dalam mendidik anak didiknya. Namun, penguasaan teknologi akan membedakan keeksisan antara guru yang satu dengan yang lainnya. Guru biasanya menggunakan lebih banyak teknologi ketika mereka merasakan banyaknya manfaat dari penggunaan teknologi tersebut (Zhang \& Espinoza, 1998; Lam, 2000). Karena itu, guru perlu memiliki strategi yang jitu untuk memfasilitasi terjadinya pembelajaran yang menyenangkan dan tepat sasaran bagi anak didiknya. Salah satunya adalah dengan penggunaan media pembelajaran yang didukung teknologi. Artinya literasi teknologi memang perlu dipahami dengan baik dan mendalam oleh seorang guru maupun calon guru.

Kemudahan dan keluasan akses untuk memperoleh media ataupun materi ajar perlu diiringi dengan kebijaksanaan dalam penggunaanya. Perlu dilakukan penyaringan terkait relevansinya dengan anak didik, aspek moral, kejujuran dan tanggungjawab. Literasi teknologi secara tersirat juga mengajarkan tentang karakter. Menghargai hasil karya orang lain dengan mencantumkan sumber merupakan salah satu dari karakter yang dapat dibentuk. Literasi teknologi diharapkan juga dapat mengatasi budaya mencontek dan asal jadi yang biasa dilakukan mahasiswa dalam menyelesaikan tugas-tugas perkuliahan.

Revolusi indistri 4.0 yang ditandai dengan semakin berkembang dan meluasnya internet menjadi tantangan sendiri bagi calon pendidik sekolah dasar. Mereka diharapkan dapat lebih bijak dalam bermedia sosial, menggunakan internet secara positif, dan tidak menghabiskan waktu dengan main games online. Mengajar di sekolah dasar tentunya memiliki tantangan sendiri. Guru yang lebih melek teknologi tentunya lebih diterima oleh anak didiknya. Namun, guru yang cerdas berteknologi dan memiliki karakter yang baik yang diwujudkannya dalam pemilihan dan pengembangan media ataupun materi ajar yang tepat bagi anak didknya tentunya lebih dinantikan keberadannya.

\section{KESIMPULAN}

Literasi teknologi bukan sekedar melek teknologi namun lebih dari itu adalah suatu pemahaman yang baik terhadap pemanfaatan teknologi, bagaimana mengimplementasikan pemahaman tersebut dalam bentuk pengembangan teknologi yang dapat dipergunakan dalam dunia pendidikan. Keberadaan literasi teknologi ini diyakini sebagai salah satu dampak dari era 4.0 yang membawa perubahan yang sangat signifikan dalam kehidupan masyarakat. Dari sudut pandang calon pendidik sekolah dasar diperoleh bahwa penggunaan teknologi merupakan suatu keharusan dalam pembelajaran. Dengan teknologi proses pembelajaran dapat lebih menyenangkan dan variatif. Tapi tentunya bijak berteknologi, inovatif dan kreatif merupakan karakteristik yang diharapkan dari seorang guru. 


\section{DAFTAR RUJUKAN}

Courville, Keith. (2011). Technology and its use in Education: Present Roles and Future Prospects. Paper Presented at the 2011 Recovery School District Technology Summit thth(June 6 8 2011, Baton Rouge, Louisiana) Session Name: Current Trends and Recommendations in Technology

Fu, Jo Shan. (2013). ICT in Education: A Critical Literature Review and Its Implications. International Journal of Education and Development using Information and Communication Technology. (IJEDICT). 2013, Vol. 9, Issue 1, pp. 112-125

Gorra, Virginia Carbonilla dan Bhati, Shyam S. (2016). Students' perception on use of technology in the classroom at higher education institutions in Philippines. Asian Journal of Education and e-Learning. (ISSN: 2321 - 2454) Volume 04 - Issue 03, June 2016

Hutchinson, Tom dan Waters, Alan. (1987). English for Specific Purposes. Cambridge University Press.

Lam,Y. (2000). Technophiliacs,technophobia: A preliminary look at why second-language teachers do or do not use technology in their classrooms. Canadian Modem Language Review, 56(3), 389-420.

Maryland State Department of Education. (2005). Maryland Technology Education State Curriculum. [Online].Tersedia di marylandpublicschools.org

Miles, Matthew B dan A. Michael Huberman. (1994). Qualitative Data Analysis. An Expanded Source Book. $2^{\text {nd }}$ Edition. Sage Publications, Inc.

National Academy of Engineering and National Research Council of The NationalAcademis.( 2006). Tech Tally: Approaches to Assessing Technological Literacy. [Online]. Tersedia di http:/ /download.nap.edu/cart/download.cgi?\&record_id=11691\&free=1

Permatasari, A. (2015). Membangun kualitas bangsa dengan budaya literasi. Prosiding Seminar Nasional Bulan Bahasa UNIB

Rose, Annette Mary. (2007). Perceptions of Technological Literacy among Science, Technology, Engineering, and Mathematics Leaders. Journal of Technology Education. Vol. 19 No. 1, Fall 2007 [Online].

Sadiman, Arief S., Rahardjo, R., Haryono, Anung, dan Rahardjito. (2011). Media Pendidikan. Pengertian, Pengembangan dan Pemanfaatannya. Jakarta: Rajawali Pers

Sanaky, Hujair AH. (2009). Media Pembelajaran. Yogyakarta: Safiria Insania Press 
Sudjana, Nana dan Rivai, Ahmad. (2011). Media Pengajaran: Penggunaan dan Pembuatannya. Bandung: Sinar Baru Algesindo

Sumantri, Mohamad Syarif. (2016). Strategi Pembelajaran. Teori dan Praktik di Tingkeat Pendidikan dasar. Jakarta: Rajawali Pers.

Susanto, Ahmad. (2013). Teori Belajar dan Pembelajaran di Sekolah Dasar. Jakarta: Kencana.

Solanki D. Shyamlee, M Phil. (2012). Use of Technology in English Language Teaching and Learning": An Analysis International Conference on Language, Medias and Culture. IPEDR vol.33 (C) (2012) IACSIT Press,Singapore

Teguh, M. (2013). Gerakan Literasi Sekolah Dasar. In Prosiding Seminar Nasional Aktualisasi Kurikulum (pp. 18-26).

Zhang, Y. \& Espinoza, S. (1998). Relationship among computer self-efficacy, attitudes toward computers, and desirability of learning computing skills. Journal of Research and Computing in Education, 30(4), 420-438. 